\title{
Company Profitability and Size as A Description of Capital Structure and Its Effect on Company Value in Food and Beverage Companies in Indonesia Stock Exchange
}

\author{
Yuhasril,Yuhasril Tri Wahyono Sumiyarsih,Sumiyarsih \\ Trisakti School of Management
}

\begin{abstract}
This study aims to analyze profitability, company size and capital structure on firm value. The population in this study is the food and beverage sub-sector companies listed on the main board on the Indonesia Stock Exchange. The sample used is as many as 60 samples calculated based on 10 companies for the period 2014-2019. The sampling method used was purposive sampling. The data analysis method used descriptive method and panel data regression. This study proves that profitability and firm value do not have a significant effect on capital structure. Profitability and capital structure have a significant positive effect on firm value. Firm size has no positive effect on firm value.
\end{abstract}

Keywords: Profitability, company size, capital structure, firm value, food and beverage sub-sector.

DOI: $10.7176 / \mathrm{EJBM} / 13-11-06$

Publication date:June $30^{\text {th }} 2021$

\section{INTRODUCTION}

Industry makan and drink also one aspect of management and that that in providing a large contribution to the economic growth tatal. The Ministry of Industry noted that the food and beverage industry is a sector that has a significant contribution to the national economy. In 2019, the growth of the food and beverage industry will reach $7.78 \%$. This figure is higher than the growth of the non-oil and gas industry at $4.34 \%$ and the growth of the national industry at 5.02 percent. In addition, in the same year, the food and beverage industry sector also contributed up to $36.40 \%$ of the GDP of the non-oil and gas processing industry. This shows the important role of the food and beverage industry in industrial growth and the national economy (www.antaranews.com).

Competition in the sub-sector industry means and drinks make every effort as likely as possible to increase the performance of their goals that they can reach. The main goal of maintaining the defense is often defined is to increase the degree of integrity of the shareholder. . The following is a graphical representation of the importance of the value of the damage measured by Tobin's Q, shown in Figure 1.1:

Graphic of graduate of advanced direction of GDP growth of management and drinking with the value of destruction of the maintenance of the sub seb-sector of managing and drinking about PAD 2014.

Figure 1.

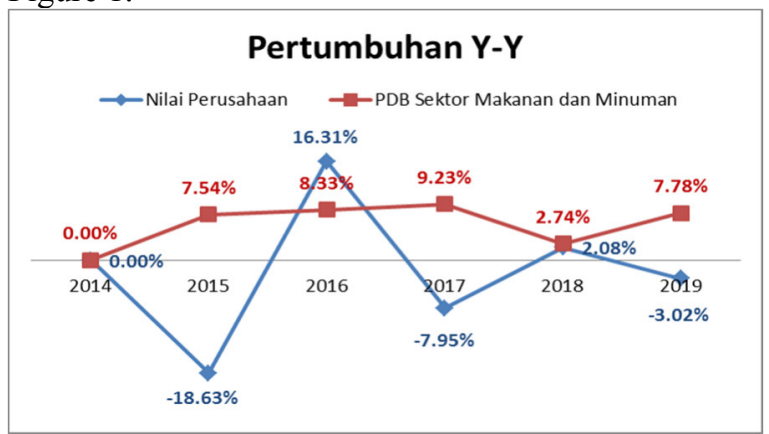

Source: idx.co.id (data processed, 2020)

Bps.go.id (data processed, 2020.

Such numbers have maintained that the sub-sector's destruction of food and drink during 2014-2019 has fluctuated quite drastically. In line with this, practice from the perception of the value of the damage is not easy and it takes quite a long time, even though it is called a display of display support.

General defects will be concerned with the power disruptions such as dividend disruptions, investment disruptions and modality differences in terms of the structure of the structure. In fact, from the discontinuity of understanding, there has always been too much problem related to the choice and combination of sources and sources. The source and the amount of damage has been recovered from the damage which was several years ago. This is what is the dilemma of damage in keeping with them several servings of different sources of money. The true proportion will affect the capital structure of the destruction.

This research focuses on two variants that are considered to have the most significant influence on how to 
find out the most destructive differences in understanding.

\section{LITERATURE REVIEW}

\section{The value of the company.}

Firm value is the market value of all financial components of a company if the company is sold which is reflected in the company's share price. In other words, company value is the perception of investors or shareholders on the prospects of a company which can be seen from the company's stock price.

\section{Capital Structure.}

The capital structure is a consideration of the amount of permanent short-term debt, long-term debt, preferred stock, and common stock (Hamidah, 2019).

Capital structure refers to the source of company funding. Funding can range from relatively permanent equity capital to a more risky, temporary short-term source of funding. When obtaining funding, the company will invest it in various assets. Assets represent a secondary source of security for lenders and are derived from loans guaranteed by certain assets to assets that are available as general security for unsecured creditors. These and other factors produce different risks associated with different assets and sources of funding.

\section{Debt to Equity Ratio (DER)}

Debt to Equity Ratio (DER) is one of the ratios used to describe the company's capital structure. Debt to Equity Ratio (DER). This ratio is sought by comparing all debt, including current debt, and total equity. This ratio is useful for knowing the amount of funds provided by the guarantor (creditor) and the owner of the company. In other words, this ratio serves to determine each rupiah of own capital that is used as debt collateral (Kasmir, 2017).

\section{Pecking Order Theory}

It is a theory that describes a level in the search for company funds which shows that companies prefer to use internal equity in financing investment and implement it as a growth opportunity. This theory states that companies prefer internal funding to external funding, safe debt than risky debt and the last is common stock (Myers \& Majluf, 1984 in Sugiarto 2009). It can be said in this theory that companies with high levels of profitability are in fact low levels of debt because companies with high profitability have abundant internal sources of funds.

\section{Company Size}

Febriyanti and Yahya (2017), a large company size is considered as an indicator that describes the level of risk for investors to invest in the company, because if the company has good financial capabilities, it is believed that the company is also able to fulfill all its obligations and provide an adequate rate of return for investors. So, the size of the company is the size of the assets owned by the company. Therefore, it is possible for large companies to have a greater level of leverage than small companies.

\section{Profitability}

Profitability is always associated with profit. Profitability is usually used to measure the extent to which the company's performance has been achieved in terms of profit. Profitability According to Kasmir (2017), the profitability ratio is a ratio to assess a company's ability to seek profits in the form of company profits and economic value on sales, company net assets and own capital. Research conducted by Febriyanti and Yahya (2017) states that profitability has a significant effect on capital structure.

\section{HYPOTHESIS}

Profitability Relationship With Capital Structure

Profitability is a ratio to assess a company's ability to seek profits (Kasmir, 2017). Companies with a high rate of return tend to use more of a relatively small proportion of debt. The higher the profitability, the higher the profit the company gets. If the company's profit is high, the company has a source of funds. It can be concluded that the relationship between profitability and capital structure is positive.

H1: Profitability affects the capital structure.

Relationship between Company Size and Capital Structure

The size of the company is seen from the size of the assets owned by the company. Small companies tend to have higher costs of capital and short-term debt costs than large companies. So 22 small companies tend to prefer shortterm debt over long-term debt because the costs are lower. The larger the size of a company, the greater the tendency to use foreign capital and the greater the possibility of obtaining loans from creditors to meet the targeted company's capital structure. Research conducted by Che Fei (2019), Hirdinis (2019), Bilgin (2019) shows a positive relationship between size and capital structure. It can be concluded that the relationship between company size and capital structure is positive. 
H2: Firm size affects the capital structure.

Profitability Relationship with Company Value

profit, which is reflected by profitability, is one of the things that attract investors. The greater the profit generated, it will give a positive signal to investors, which will provide dividends to investors when investing in the company. This will have implications for the increase in company value (Dewi \& Wirajaya, 2013). Research conducted by Ganang, et al (2019), Dahar, et al (2019), Dewi, et al shows a positive relationship between profitability and firm value. It can be concluded that the relationship between profitability and firm value is positive.

H3: Profitability affects firm value.

Relationship between Company Size and Firm Value

Research conducted by Hirdinis (2019) shows a positive relationship between company size and firm value. It can be concluded that the relationship between size and firm value is positive.

H4: Firm size has an effect on value.

Relationship between Capital Structure and Company Value.

This is in line with the trade off theory that companies that use large amounts of debt can increase firm value. This occurs because the effect of tax savings has an impact on company value greater than the effect of bankruptcy costs. In addition, the greater the debt to equity ratio, the greater the debt to equity funds used by the company, which in turn will affect the stock of funds in fulfilling funding, so that it will have an impact on company value. Research conducted by Hirdinis (2019) Ganang, et al (2019), Dahar, et al (2019) and Mujdidah et al (2019) shows a positive relationship between capital structure and firm value. It can be concluded that the relationship between capital structure and firm value is positive.

H5: Capital structure affects firm value.

Model 1. with the capital structure as the dependent variable.

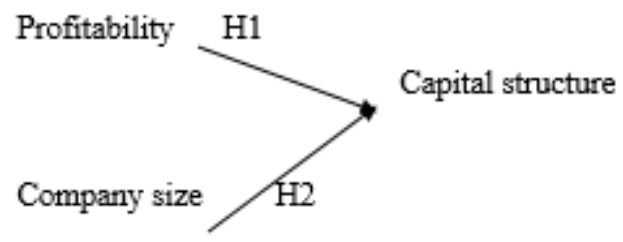

Model 2. with firm value as the dependent variable.

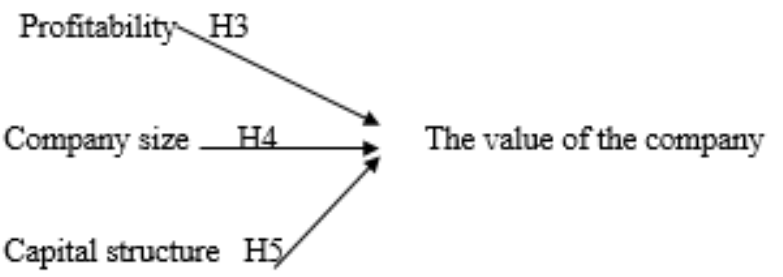

\section{RESEARCH METHODOLOGY.}

This research uses quantitative methods with an associative form. The subjects of this research are Food and Beverage companies listed on the main board on the Indonesia Stock Exchange for the period 2014-2019. Information on this research can be accessed through the official website of the Indonesia Stock Exchange, namely, www.idx.co.id. The research objects used in this study are profitability, company size, capital structure and firm value.

The population of this study is the financial statements of the food and beverage sub-sector manufacturing companies that have been selected using a purposive sampling method in accordance with predetermined criteria. The amount of data collected was 60 samples from 10 companies with a 6 year period. With the details of 10 companies as shown in table 1: 
Table 1: Research Sample Results Based on the Selection Process.

\begin{tabular}{clc}
\hline No & \multicolumn{1}{c}{ Company name } & Code \\
\hline 1 & Tri Banyan Tirta Tbk. & ALTO \\
2 & Budi Starch \& Sweetener Tbk. & BUDI \\
3 & Wilmar Cahaya Indonesia Tbk. & CEKA \\
4 & Delta Djakarta Tbk & DLTA \\
5 & Indofood CBP Sukses Makmur Tbk. & ICBP \\
6 & Indofood Sukses Makmur Tbk. & INDF \\
7 & Multi Bintang Indonesia Tbk. & MLBI \\
8 & Mayora Indah Tbk. & MYOR \\
9 & Nippon Indosari Corpindo Tbk. & ROTI \\
10 & Ultra Jaya Milk Industry \& Tra & ULTJ \\
\hline
\end{tabular}

Sumber: www.idx.co.id (2019)

The variables used in this research consist of:

X1: Profitability

$\mathrm{X} 2$ : Company Size

Y1: Company Value

Y2: Capital Structure

Probability and firm size are the independent variables, capital structure is the dependent variable, while capital structure is the independent variable for firm value as the dependent variable.

\section{Variable Operations :}

The value of the company $(\mathrm{Y} 1)=$ Tobin' $^{\prime} \mathrm{Q}=\frac{(\text { Equity Market Value }+ \text { Total Liabilities })}{\text { Total Asset }}$

Capital Structure $(\mathrm{Y} 2)=D E R=\frac{\text { Total Liabilities }}{\text { Total Equity }} \times 100 \%$

Profitability $(\mathrm{X} 1) \quad=R O A=\frac{\text { Net Prof it }}{\text { Total Asset }} \times 100 \%$

Company size $(\mathrm{X} 2) \quad=$ Firm Size $=\ln ($ Total asset $)$

In this study using descriptive test to describe the characteristics of the variables used in a study.

The panel data regression test in this study used a two-model approach, the first model with the capital structure as the dependent variable and the second model with firm value as the dependent variable.

Model 1 tests the determinants of capital structure regression.

Model 2 tests Firm Value regression.

$$
Y_{2}=a+\beta_{1} X_{1} i t+\beta_{2} X_{2} i t+\varepsilon i t
$$

Information:

$$
Y_{1}=a+\beta_{1} X_{1} i t+\beta_{2} X_{2} i t+\beta_{3} Y_{2} i t+\varepsilon i t
$$

Y1: Firm value which is the dependent variable.

Y2: Capital structure as the dependent variable and the independent variable on Y1

a: Constant, the value of Y1 or Y2 when the independent variable is 0 .

$\beta 1$ : Multiple regression coefficient between the independent variables X1 against $Y 1$, if X2 and $Y 2$ are considered constant.

$\beta 2$ : Multiple regression coefficient between the independent variables X2 against $Y 1$, if $X 1$ and $Y 2$ are considered constant.

$\beta 3$ : Multiple regression coefficient between the independent variables $\mathrm{Y} 2$ against $\mathrm{Y} 1$, if $\mathrm{X} 1$ and $\mathrm{X} 2$ are considered constant.

$\mathrm{X} 1$ : Profitability, is the 1 st dependent variable

$\mathrm{X} 2$ : Profitability, is the 2nd dependent variable

$\varepsilon$ : bully error.

Because this research uses panel data regression, the model selection test is carried out first with the Chow test, Hausman test and LM test. Then perform the classical assumption test which consists of Normality Test, Multicollinearity Test, Heteroscedasticity Test and Autocorrelation Test. While the hypothesis test uses the F test, $t$ test and the coefficient of determination test.

\section{Hypothesis Testing}

Simultaneous Test (Test F)

The F test is carried out to see the effect of the independent variables as a whole on the dependent variable. This test is done by comparing the calculated F value with the F table. According to Nachrowi (2006), the F test is used to test the effect of the independent variable simultaneously on the dependent variable. If the independent variable has a simultaneous influence on the dependent variable, the regression equation model is included in the fit criteria. 
Conversely, if there is no multanimatic influence then this will fall into the unsuitable or non-fit category.

According to Nachrowi (2006), to conclude whether the model falls into the fit category or not, we must compare the calculated $F$ value with the $F$ table with df of $k$ and $n-k-1$. The basis for the decision is if the value of $F$ count $>$ $\mathrm{F}$ table, then $\mathrm{H} 0$ is rejected or in other words that there is at least one regression slope which is statistically significant.

The hypothesis in the first model to be tested is related to whether there is a simultaneous influence on the determinants of capital structure and whether or not the size of the company and industry has a moderating effect on the relationship between capital structure and its determinants. This relationship is measured by the regression coefficient (b) with the following criteria:

Ho: $\mathrm{b} 1=\mathrm{b} 2=0$

Ho: simultaneous profitability and firm size do not affect capital structure

Ha: $\mathrm{b} 1 \neq \mathrm{b} 2 \neq 0$

Ha: profitability and firm size simultaneously affect capital structure

\section{Partial Test (t test)}

The $t$ test is used to see the significance of the individual independent influence on the dependent variable by assuming other variables are constant. The $t$ value is used to test whether an independent variable has a significant effect on the dependent variable or not. The $t$ test is done by comparing $t$ count with $t$ table. The basis for the decision making is if $\mathrm{t}$ count $>\mathrm{t}$ table, it means that $\mathrm{H} 0$ is rejected, which means that the independent variable has a significant effect on the dependent variable, but if $t$ count $\leq t$ table, then $\mathrm{H} 0$ is accepted which means that the independent variable has a significant effect on the dependent variable.

In addition to comparing the value of $t$ table with $t$ count, to find out whether the dependent variable has a significant effect on the dependent variable in this study is also done by looking at the probability value of each independent variable.

The hypothesis in the first model that will be tested is related to whether there is an influence on each determinant of capital structure and whether there is a moderating effect of company size and industry on the relationship between capital structure and its determinants. This relationship is measured by the regression coefficient (b) with the following criteria:

Empirical model statistical hypothesis 1

$\mathrm{H} 0: \beta 1=0$ : There is no effect of profitability on capital structure

Ha: $\beta 1 \neq 0$ : There is an effect of profitability on capital structure.

H0: $\beta 2=0$ : There is no effect of firm size on capital structure

Ha: $\beta 2 \neq 0$ : There is an effect of firm size on capital structure

The hypothesis in the second model to be tested is related to the influence of capital structure on firm value with the following criteria:

Empirical model statistical hypothesis 2

H0: $\beta 1=0$ : There is no effect of profitability on firm value

Ha: $\beta 1 \neq 0$ : There is an effect of profitability on firm value

H0: $\beta 2=0$ : There is no effect of firm size on firm value

Ha: $\beta 2 \neq 0$ : There is an effect of firm size on firm value

$\mathrm{H} 0: \beta 3=0$ : There is no effect of capital structure on firm value

Ha: $\beta 3 \neq 0$ : There is an effect of capital structure on firm value

Determination Coefficient

The coefficient of determination (R2) is used to measure how well the regression line matches the actual data (goodness of fit). The coefficient of determination (R2) is very useful for measuring the closeness between the estimated value and the real value of the dependent variable.

$\mathrm{R} 2$ value has an interval between 0 to $1(0<\mathrm{R} 2<1)$. The greater $\mathrm{R} 2$ (close to 1$)$, the better the results for the regression model and vice versa, the closer to 0 , the independent variable as a whole cannot explain the dependent variable.

\section{RESEARCH RESULT}

\section{Descriptive Statistics Test}

The descriptive test results in this study indicate that the average value of the firm value (Tobin's Q) is 3.25, with a standard deviation of 3.10 , the lowest value is 0.37 , the highest value is 12.41 , with a median value of 2,90 . The average value of DER is $97.23 \%$, with a standard deviation of 0.620740 , the lowest value is $16.35 \%$, the highest value is $302.86 \%$, with a median value of $97.88 \%$. The average value of ROA is $11.86 \%$, with a standard deviation of 0.12 , the highest ROA value is $52.67 \%$, the ROA value is $(5.6653 \%$ ), with a median value of $10.00 \%$. The average value of company size represented by $\ln$ (total assets) is 29.24328 with a standard deviation of 1.414235 , the highest value is 32.20096 , the lowest value is 27.62294 , with a median value of 28.71940 . 
Chow test.

\begin{tabular}{lccc}
\hline Effects Test & Statistic & d.f. & Prob. \\
Cross-sect. F & 23.248 & $(9,48)$ & 0.0000 \\
\hline
\end{tabular}

Source: Eviews 11, 2020.

The results of the Chow Model 2 test show that the P-value is smaller than 0.05 , which means that it can be concluded while that the Fixed Effect Model is more appropriate for Model 1.

\begin{tabular}{lrrr}
\hline Effects Test & Statistic & d.f. & \multicolumn{1}{c}{ Prob. } \\
Cross-sect. F & 17.030 & $(9,37)$ & 0.000 \\
\hline
\end{tabular}

Sumber: Eviews 11,2020

The results of the Chow Model 2 test show that the p-value is smaller than 0.05 , which means that it can be concluded that the fixed effect is more appropriate for model 1.

Hausman Test.

\begin{tabular}{lccc}
\hline Test Summary & Chi $^{2}$ Stat. & Chi $^{2}$ d.f. & Prob. \\
\hline Cross-section & 1.373689 & 2 & 0.5032 \\
\hline
\end{tabular}

Source: Eviews 11, 2020.

The results of the Hausman test show that the $p$-value of chi square is $0.5032>0.05$. The provisional conclusion is that the random effect model is more appropriate for model 1.

\begin{tabular}{|c|c|c|c|}
\hline Test Summary & Chi ${ }^{2}$ Stat. & Chi $^{2}$ d.f. & Prob. \\
\hline$\overline{\text { Cross-section }}$ & 14.03256 & 2 & 0.0029 \\
\hline
\end{tabular}

Sumber: Eviews 11, 2020

The results of the Hausman test show that the p-value of chi square is $0.0029<0.05$. The conclusion is that the Fixed effect model is more appropriate for model 2.

Uji Lagrange Multiplier (LM)

\begin{tabular}{lccc}
\hline \multirow{2}{*}{$\begin{array}{l}\text { Breush } \\
\text { Pagan }\end{array}$} & Cross-sect. & Time & Both \\
\cline { 2 - 4 } & 55.74256 & 0.3332 & 56.075 \\
& $(0.0000)$ & $(0.5638)$ & $(0.0000)$ \\
\hline
\end{tabular}

Source: Eviews 11, 2020.

The output results above show the Breush-Pagan (BP) p-value of 0.0000. So the right model 1 in the results above is the random effect model.

Results of Panel Data Regression Analysis

The results of panel data regression model 1:

$\log Y_{2}=5,5852-1,5969 X_{1}-0,2628 X_{2}+\varepsilon$

From the regression equation, it can be concluded that the value of the constant coefficient is equal to that if the variables X1 (Profitability) and X2 (Company Size) are zero, then the amount of the capital structure is.

The regressive coefficient value of X1 (Profitability) is negative, which is equal to - meaning that every $1 \%$ increase in profitability is predicted to reduce the capital structure by 1.596592 , assuming the other variables are constant.

The regressive coefficient value of X2 (company size) is negative, which is -0.262856 , meaning that every $1 \%$ increase in company size is predicted to reduce the capital structure by 0.262856 , assuming the other variables are fixed

Results of Panel Data Regression Model 2: $Y_{1}=19,162+11,828 X_{1}-0,616 X_{2}+0,720 Y_{2}+\varepsilon$

From the regression equation, it can be concluded that the constant coefficient value is equal if the variables X1 (Profitability), X2 (Company Size), Y2 (Capital Structure) are zero, then the magnitude of the capital structure is. The regression coefficient value of the variable X1 (Profitability) is positive, which means that every $1 \%$ increase in profitability is predicted to increase firm value by assuming the other variables are fixed.

The regressive coefficient value of X2 (firm size) is negative, which means that every $1 \%$ increase in company size is predicted to decrease firm value by assuming the other variables are fixed.

The regressive coefficient value of Y2 (capital structure) is positive, namely 0.720644 , meaning that every $1 \%$ increase in capital structure is predicted to increase firm value by 0.720644 , assuming the other variables are fixed. 


\begin{tabular}{ll} 
Statistical Test F. \\
\hline F-statistic & 3.126165 \\
Prob (F-statistic) & 0,051493 \\
\hline
\end{tabular}

Source: Output Eviews 11, 2020.

Based on the results of the F test, it can be seen that the value of Fcount is greater than Ftable (3.126165> 2.76) with a Prob (F-Statistic) level of 0.05 . By using a significance level of $\alpha 0.05$ or $5 \%$. So it can be concluded that there is a joint influence (simultaneously) of profitability (X1) and company size (X2) on capital structure (Y2).

\begin{tabular}{ll} 
F-statistic & 189.4570 \\
Prob(F-statistic) & 0.000000 \\
\hline
\end{tabular}

Source: Output Eviews 11, 2020.

Based on the results of the F test, it can be seen that the value of Fcount is greater than Ftable (189.4570>2.76) with a Prob (F-Statistic) level of 0.00000. By using a significance level of $\alpha 0.05$ or $5 \%$. So it can be concluded that there is a joint influence (simultaneously) of profitability (X1), company size (X2) and capital structure (Y2) on firm value (Y1).

\section{Statistical test t}

Table 2 Table of Test Results.

\begin{tabular}{clccc}
\hline Hypothesis & \multicolumn{1}{c}{ Influence between variables } & $\begin{array}{c}\text { T } \\
\text { Statistik }\end{array}$ & P Value & Information \\
\hline $\mathrm{H}_{1}$ & Profitability $\rightarrow$ capital structure & $-1,6886$ & 0,0967 & No effect \\
$\mathrm{H}_{2}$ & Firm size $\rightarrow$ capital structure & $-1,9048$ & 0,0618 & No effect \\
$\mathrm{H}_{3}$ & Profitability $\rightarrow$ firm value & 6,5731 & 0,00000 & Has a positive effect \\
$\mathrm{H}_{4}$ & Firm size $\rightarrow$ firm value & $-1,8612$ & 0,0690 & No effect \\
$\mathrm{H}_{5}$ & Capital structure $\rightarrow$ firm value. & 2,9681 & 0,0047 & Has a positive effect \\
\hline
\end{tabular}

Source: Eviews 11, 2020.

Determine Coefficient Test.

\begin{tabular}{lr}
\hline R-squared & 0.098847 \\
Adjusted R-squared & 0.067228 \\
\hline
\end{tabular}

Source: Output Eviews 11, 2020.

Shows the level of the model's explanation of the dependent variable of 0.067228 . Thus the independent variables, namely company size and profitability, have an influence on the capital structure of $6.7228 \%$.

\begin{tabular}{lr}
\hline R-squared & 0.979746 \\
Adjusted R-squared & 0.974574
\end{tabular}

Source: Output Eviews 11, 2020

Shows the level of the model's explanation of the dependent variable of 0.974574 . Thus the independent variables, namely company size, profitability and capital structure have an influence on firm value by $97.4574 \%$.

\section{DISCUSSION OF RESEARCH RESULTS}

The Effect of Profitability on Capital Structur

From the test results presented, it can be seen that the significance level (p-value) of profitability is 0.0967 ( $>$ $0.05)$. The test results show that the first hypothesis $(\mathrm{H} 1)$ which states that there is no effect of profitability on the capital structure $(\mathrm{H} 1)$ is rejected, so profitability has no effect on capital structure. The results of the study are not in line with Fei (2019) and Bilgin (2019) which concluded that profitability has a significant negative effect on capital structure. Based on the analysis in this study, it can be stated that the company does not consider the amount of profitability obtained in determining its capital structure policy because the company has determined the capital structure according to the amount of withdrawals and capital issued due to the use of profits to support the company's operations.

\section{The Effect of Company Size on Capital Structure}

- From the research results, it can be seen that the level of significance (p-value) of the company size is $0.0618(>0.05)$. The test results indicate that the second hypothesis $(\mathrm{H} 2)$ which states that there is an effect of company size on capital structure $(\mathrm{H} 2)$ is rejected. The results of the study are in line with Sethiadarma (2017) which states that there is no influence of company size variables on capital structure.

- The results of this study indicate that a large company size will not affect the capital structure of the company because a large company size indicates that the company has a large internal source of funds or 
retained earnings, so that the company is able to finance the investment with the funds it collects.

\section{The Effect of Profitability on Firm Value}

- From the test results, it can be seen that the level of significance ( $p$-value) of profitability to firm value as proxied by Tobin's Q Score is $0.0000(<0.05)$. The test results show that the third hypothesis $(\mathrm{H} 3)$ which states that there is an effect of profitability on firm value (H3) is accepted, then profitability has a positive effect on firm value. The results of the study are in line with previous research conducted by Ganang (2019) and Dahar (2019) and Dewi (2013) which show that the profitability variable has a positive effect on firm value.

- If the company gets a high level of profit, it will attract investors' interest in investing in the company, this kind of thing is also a positive signal received by investors that a company that gets a high profit rate means that the company has good prospects in the future. will come which will affect the rate of return on investment. The more investors who are attracted to the company, the more the company's stock price will increase, which reflects the company's high value. In this study it can also be concluded that profitability is one of the things that investors pay attention to in determining the value of a company, therefore company managers should further improve company performance to get a high level of profitability.

\section{The Effect of Firm Size on Firm Value}

- From the research results, it can be seen that the level of significance (p-value) of the company size is $0.0690(>0.05)$. The test results show that the fourth hypothesis $(\mathrm{H} 4)$ which states that there is an effect of firm size on firm value (H4) is rejected. The results of this study are in line with Hirdinis (2019) which states that there is no effect of company size on firm value.

- In this case, investors in the food and beverage sub-sector company do not really care about the size of the company whether it has large assets or small assets as long as the company is generating profits, where the main objective of a company is to make a profit. These investors will look more at various other aspects such as paying attention to the company's performance, which can be seen in the company's financial statements, which can be in the form of profitability or the capital structure used. Based on the research results, company size large or small will not be able to influence firm value.

\section{The Effect of Capital Structure on Firm Value}

From the test results, it can be seen that the level of significance ( $p$-value) of capital structure on firm value is $0.0047(<0.05)$. The test results show that the fifth hypothesis (H5) which states that there is an effect of profitability on firm value (H5) is accepted, then the capital structure has a positive influence on firm value. The results of the study are in line with previous research conducted by Hirdinis (2019), Ganang (2019) and Dahar (2019) and Mujdidah (2019) which show that capital structure variables have a positive effect on firm value. This shows that if the company increasingly uses long-term debt to finance its assets, it can increase company value. This is in accordance with the Trade off theory where companies can take advantage of debt while the benefits (tax savings and other costs) are compared with the sacrifice (paying interest). In addition, it is also in accordance with the Signaling theory which states that when a company uses internal funds to fund its business it will be seen by investors as a significant positive signal because investors' perceptions when a company uses debt mean that the company has the ability to increase capacity and pay off debt.

\section{CONCLUSIONS AND SUGGESTIONS Conclusion}

Based on the results of the research and discussion in chapter IV that has been done, it can be concluded as follows: 1. Partially profitability does not have a significant effect on the capital structure of the food and beverage subsector companies listed on the main board on the Indonesia Stock Exchange for the 2014-2019 period.

2. The size of the company partially does not have a significant effect on the capital structure of the food and beverage sub-sector companies listed on the main board on the Indonesia Stock Exchange for the 2014-2019 period. 3. Profitability partially has a positive and significant effect on firm value in the food and beverage sub-sector companies listed on the main board on the Indonesia Stock Exchange for the 2014-2019 period. These results indicate that each increase in profitability increases firm value.

4. Company size partially does not have a significant effect on firm value in the food and beverage sub-sector companies listed on the main board on the Indonesia Stock Exchange for the 2014-2019 period.

5. The capital structure partially has a positive and significant effect on firm value in the food and beverage subsector companies listed on the main board on the Indonesia Stock Exchange for the 2014-2019 period. These results indicate that each increase in capital structure increases firm value. 


\section{Suggestions.}

Based on the results of research and discussion, the suggestions that can be given by researchers are as follows:

1. For companies, this research can serve as a reference for company management in making policies and become information that can assist management in making decisions regarding the application of corporate value. The practice of increasing company value carried out in a company is able to provide certain benefits for the company. It is recommended that companies determine the capital structure by using debt at a certain level (as long as the benefits are greater, additional debt is allowed) as a source of funding.

2. For investors, this research becomes a reference for investors in choosing where to invest in companies in the food and beverage sub-sector, namely by considering the level of profitability and capital structure decisions if the value of the company is prioritized in investing. Investors can be more selective in investing by choosing a company that has a high level of profitability and low use of debt in the company, so the opportunity to maximize the value of the company will be even greater.

3. For Researchers Furthermore, for researchers, especially those interested in examining the determinants of capital structure that affect firm value, it is suggested to conduct further research by expanding the determinant variable of capital structure. This study only uses two variables of capital structure and capital structure itself to determine their effect on firm value

\section{BIBLIOGRAPHY}

Bilgin, R .. \& Dinc, Y. (2019). Factoring as a determinant of capital structure for large firms: Theoretical and empirical analysis. Journal of Management. Borsa Istanbul, DOI: 10.1016 / j.bir. 2019.05.001

Bringham, E., F. \& Huston, J., F. (2019). Fundamentals of Financial Management, Fifteenth Edition, Cengage, Boston.

Central Bureau of Statistics, Gross Domestic Product, 2010-2018. (accessed at http://www.bps.go.id)

Indonesia Stock Exchange, Annual financial reports 2014, 2015, 2016, 2017 and 2018. (accessed at http://www.idx.co.id)

Chandra, T. (2019). The effect of capital structure on profitability and stock returns Empirical analysis of firms listed in Kompas 100, DOI: 10.1108 / JCEFTS-11-2018-0042

CNN Indonesia. 2015 Investment Dropped, Food Industry Puts Happiness in 2016. (accessed at http: //www.CNN).

Dahar, R., Yanti, N.S.P. \& Rahmi, F. (2019). The Influence of Capital Structure, Company Size and Equity on the Value of Property and Real Estate companies listed on the Indonesia Stock Exchange. Journal of Financial Management, 21.

Erawat, L. \& Dewi, A.S. (2018). The Role of Profitability as an Intervening Variable and the Influence of Capital Structure on Firm Value. Journal of Financial Management.

Ganang D. P., (2019). The Effect of Leverage and Capital Structure on Company Value With Profitability As Mediation Variable. Journal of Financial Management.

Ghozali, I., \& Ratmono, D. (2018). Multivariant and Econometric Analysis: Theory, Concepts and Applications with Eviews 10. Prints II, Bdan Publisher-Undip, Semarang.

Goh, C.F., Tai, W.Y., Rasli, A., Tan, O.K. \& Zakoan, N. (2018). The Determinants of Capital Structure: Evidence from Malaysian Companies. Journal of Financial management, 7(3). ISSN: 2050-7399.

Hamidah (2019). Financial management, Original Edition, Mitra Wacana Media, Jakarata.

Hartono, J. (2015). Portifolio Theory and Investigation Analysis, BPFE, Yogyakarta

Hirdinis, M. (2019). Capital Structure and Firm Size on Firm Value Moderated by Profitability, 7.

Husnan, Suad, (2015). Fundamentals of Financial Management, Seventh Edition, UPP STIM YKPN, Yogyakarta.

Irham F. (2017). Financial report analysis, Alfabeta, Bandung.

Cashmere (2017). Financial statement analysis, First Edition, Rajawali Pers, Jakarta.

Cashmere (2019). Introduction to Financial Management, Second Edition, Kencana, Jakarta.

Mudjija, S., Khalid, Z. \& Astuti, D.A.S. (2019). The Influence of Financial Performance and Capital Structure on Firm Value Moderated by Firm Size Variable. 8 (1).

Riny, (2018). Analysis of Factors Affecting Company Value in Consumer Goods Companies Listed on the Indonesia Stock Exchange. 8 (2). ISSN 2622-6421

Sarinah \& Mardalena (2017), Introduction to Management, First Edition, Deepublish, Yogyakarta.

Sartono, A., (2012). Financial Management Theory and Applications. Issue 4. BPFE. Yogyakarta.

Setiadharma S. \& Machali M. (2017). The Effect of Asset Structure and Firm Size on Firm Value with Capital Structure as Intervening Variable, 6, DOI: 10.4172 / 2167-0234.1000298

Sriyana, J. (2014). Panel data regression method, First Edition, Ekonisia, Yogyakarta.

Sugiono, A., \& Untung, E. (2016). Basic Practical Guide to Financial Statement Analysis, Grasindo, Jakarta.

Sugiyono, (2017). Qualitative Research Methods, Quantitative and R \& D, Alfabeta, Bandung.

Sujarweni Wiratna, V. (2019). Research Methodology, Pustakabarupress, Yogyakarta.

Suprihanto, J., (2014). Management, Gajah Mada University Press, Yogjakarta. DAFTAR PUSTAKA 
Bilgin, R.. \& Dinc, Y. (2019). Factoring as a determinant of capital structure for large firms: Theoretical and empirical analysis. Journal of Management. Borsa Istanbul, DOI:10.1016/j.bir.2019.05.001

Bringham, E., F. \& Huston, J., F. (2019). Fundamentals of Financial Management, Edisi Kelima Belas, Cengage, Boston.

Badan Pusat Statistik, Produk Domestik Bruto tahun 2010-2018. (diakses di http://www.bps.go.id)

Bursa Efek Indonesia, Laporan keuangan Tahunan 2014, 2015, 2016, 2017 dan 2018. (diakses di http://www.idx.co.id)

Chandra, T. (2019). The effect of capital structure on profitability and stock returns Empirical analysis of firms listed in Kompas 100, DOI:10.1108/JCEFTS-11-2018-0042

CNN Indonesia. 2015 Investasi Anjlok, Industri Makanan Menaruh Asa pada 2016. (diakses di http://www.CNN).

Dahar, R., Yanti, N.S.P. \& Rahmi, F. (2019). Pengaruh Struktur modal, Ukuran Perusahaan dan Equity Terhadap Nilai perusahaan Property and Real Estate yang Terdaftar di Bursa Efek Indonesia. Jurnal Manajemen Keuangan, 21.

Erawat, L. \& Dewi, A.S. (2018). Peran Profitabilitas sebagai Variabel Intervening dan pengaruh Struktur Modal Terhadap Nilai Perusahaan. Jurnal Manajemen keuangan.

Ganang D. P., (2019). The Effect of Leverage and Capital Structure on Company Value With Profitability As Mediation Variable.Journal of Financial Management.

Ghozali, I., \& Ratmono, D. (2018). Analisis Multivariant dan Ekonometrika: Teori, Konsep dan Aplikasi dengan Eviews 10. Cetakan II, Bdan Penerbit-Undip, Semarang.

Goh, C.F., Tai, W.Y., Rasli, A., Tan, O.K. \& Zakoan, N. (2018). The Determinants of Capital Structure: Evidence from Malaysian Companies. Journal of Financial management, 7(3). ISSN: 2050-7399.

Hamidah (2019). Manajemen keuangan, Edisi Asli, Mitra Wacana Media, Jakarata.

Hartono, J. (2015). Teori Portifolio dan Analisis Investatsi, BPFE, Yogyakarta

Hirdinis, M. (2019). Capital Structure and Firm Size on Firm Value Moderated by Profitability, 7.

Husnan, Suad, (2015). Dasar-dasar Manajemen Keuangan, Edisi ketujuh, UPP STIM YKPN, Yogyakarta.

Irham F. (2017). Analisis laporan Keuangan, Alfabeta, Bandung.

Kasmir (2017). Analisis laporan keuangan, Edisi Pertama, Rajawali Pers, Jakarta.

Kasmir (2019). Pengantar manajemen Keuangan, Edisi Kedua, Kencana, Jakarta.

Mudjija, S., Khalid, Z. \& Astuti, D.A.S. (2019). Pengaruh Kinerja Keungan dan Struktur Modal Terhadap Nilai Perusahaan yang Dimoderasi Variabel Ukuran Perusahaan. 8(1).

Riny, (2018). Analisis Faktor-faktor yang Mempengeruhi Nilai Perusahaan Pada perusahaan Consumer Goods yang Terdaftar di Bursa Efek Indonesia. 8(2). ISSN 2622-6421

Sarinah \& Mardalena (2017), Pengantar Manajemen, Edisi Pertama, Deepublish, Yogyakarta.

Sartono, A., (2012). Manajemen Keuangan Teori dan Aplikasi. Edisi 4. BPFE. Yogyakarta.

Setiadharma S. \& Machali M. (2017). The Effect of Asset Structure and Firm Size on Firm Value with Capital Structure as Intervening Variable, 6, DOI: 10.4172/2167-0234.1000298

Sriyana, J. (2014). Metode regresi Data Panel, Edisi Pertama, Ekonisia, Yogyakarta.

Sugiono, A., \& Untung, E. (2016). Panduan Praktis Dasar Analisa Laporan Keuangan,, Grasindo, Jakarta.

Zulkifli, Endri, Augustina Kurniasih, Determinants of the Internal Dividend Payout Ratio of Pharmaceutical Companies Listed on the Indonesian Stock Exchange, Journal of Finance and Banking, 21 (2): 238-252, 2017. 